Vol. 01, No. 2, July 2017, 98-120

Avalaible at: https://ojs.unud.ac.id/index.php/UJLC

E-ISSN 2549-0680

\title{
Knitting the Future Story of Indian Women: Preventing Violence, Fostering Development, and Accelerating Empowerment
}

\author{
Prerna S Ramteke* \\ Department of Sociology, Maniben Nanavati Womens College, \\ Vile Parle (West), Mumbai-India
}

\begin{abstract}
Women in ancient India were referred as goddesses like Kali, Durga, Laxmi that lead to the respect of women in an appropriate way. The present situation indicates how they become more vulnerable. This article highlights the issue of women in India and to describe the violence against women in India that degrades their dignity as a human being, to analyse both conceptual and practical aspects of women, particularly with regards to their role in the development and also to discuss the need for accelerating the empowerment of women in India. Some concepts such as the three classical approaches to the relationship between women and development are discussed in this writing. It also analyses the present situation faced by Indian women that can potentially become obstacles to their development. In addition, this paper looks at some legal instruments and cases that relate to the legal protection of women in India. It is a research in the field of Sociology that will be enriched by legal, cultural and economic approaches. It will also highlight the dreams of better status of women in India that are expected to become true and will also encourage women in India to get involved in many efforts to knit their future story.
\end{abstract}

Keywords: Women, India, Violence, Development, Empowerment.

How to Cite: Ramteke, Prerna S. 2017. "Knitting The Future Story Of Indian Women: Preventing Violence, Fostering Development, And Accelerating Empowerment”. Udayana Journal Of Law And Culture 1 (2): 98-120. doi:10.24843/UJLC.2017.v01.i02.p02.

DOI: https://doi.org/ 10.24843/UJLC.2017.v01.i02.p02

Copyright (C) 2017 UJLC. All right reserved

\section{Introduction}

\subsection{Background}

A large number of cases highlight that women in India are exploited even worse than animals. Among the G20 nations, India has been labelled the worst place to be a woman. ${ }^{2}$ India has also been put on the list of the 10 most dangerous countries to

\footnotetext{
Correspondence: prerna.ramteke71@gmail.com
}

1 Human Rights Watch, "Treated Worse than Animals: Abuses against Women and Girls with Psychosocial or Intellectual Disabilities in India",https: / /www.hrw.org/report/2014/12/03/treated-worseanimals/abuses-against-women-and-girls-psychosocial-or-intellectual

2 "Why India Bad for Women?", https://www.theguardian.com/world/2012/jul/23/why-indiabad-for-women 
be a woman due to cases of rape, child marriage, and human trafficking. ${ }^{3}$ Moreover, as estimated by researchers, there have been plenty cases of female infanticide or sex-selective abortions (feticide) for a son or a male child. ${ }^{4}$ It is generally spoken that there are a number of structural factors that are negatively associated with women's position in Indian society such as the role of religion, to view her as a commodity, the caste system, patriarchy and the vast urban-rural divide. ${ }^{5}$

The conferment of a prestigious International Women of Courage Award to Ms. Laxmi by the United States of America's First Lady Michelle Obama in 2014, ${ }^{6}$ was an awakening to the world. Laxmi is a victim of an acid attack in India at the age of 16. She was attacked (with acid) by her friend, a 32 years old man. ${ }^{7}$ Acid attacks are common in India, usually to avenge a woman or out of jealousy, where the attacker aims to scar a woman not only mentally but physically for life. ${ }^{8}$ This case eventually inspired a progressive law creation for almost a decade after the attack, as in 2013, India's Supreme Court ordered states to enforce restrictions on the sale of acid in a bid to curb attacks. ${ }^{9}$ In 2016, a landmark judgment for an acid attack-related case against woman has been ruled for the very first time when an Indian court has awarded the death penalty to a man who was found guilty of hurling sulphuric acid, until death on a woman in Mumbai. ${ }^{10}$

Socially, women in India were always progressive and also contributed to the welfare and justice for women. ${ }^{11}$ But the implementation of laws granting rights to women has been slow, lopsided and haphazard that women continue to socially, economically and politically lag far behind men. ${ }^{12}$ Gita Mittal, Judge Delhi High Court, stated "Despite the host of progressive and protective legislations, social justice to women has remained an anachronism. It is the judiciary alone which has risen to the

3 "10 of the Most Dangerous Countries to be A Woman", https://www.theneweconomy.com/ insight/ 10-of-the-most-dangerous-countries-to-be-a-woman

4 Swami Agnivesh, Rama Mani and Angelika Köster-Lossack, "Missing: 50 Million Indian Girls", http:/ /www.nytimes.com/2005/11/25/opinion/missing-50-million-indian-girls.html.

5 Kolaskar, Ashok S. and Dash, Motilal (eds.), "Review on Women and Society: The Road to Change", http:/ / www.socresonline.org.uk/18/3/reviews/3.html.

6 "Michelle Obama to Honour Acid Attack Victim Laxmi", http://www.thehindu.com/news/international/world/michelle-obama-to-honour-acid-attack-victim-laxmi/article5750391.ece.

7 "Best and Worst Things that Happened to Women in 2014", https://www.jaagore.com/ power-of49/ best-and-worst-things-that-happened-to-women-in-2014.

$8 \quad$ Ibid.

9 "Acid Attack: Indian Court Sentences to Death for Murder after Marriage Proposal Rejected", http:/ /www.abc.net.au/news / 2016-09-09/acid-attack-indian-court-sentences-man-to-death-formurder/7828180.

10 Ibid.

11 See R.N. Mangoli and Ganapati M. Tarase, "Crime Against Women in India: A Statistical Review", International Journal of Criminology and Sociological Theory 2, No. 2 (2009): 293, http://ijcst.journals. yorku.ca/index.php/ijcst/article/download/23401/21601.

12 Ibid. 
occasion and its role in ensuring gender justice can by no means be underplayed."13

A United Nations document that was published in 2015 highlights some issues on women in India. ${ }^{14}$ It is accounted that the male population in India is much higher than female (that is 43 million). ${ }^{15}$ The document also revealed that the country with the lowest sex ratio, in under-5 mortality, is India, with a ratio of 93 (93 boys die before age 5 for 100 girls that die by that age). ${ }^{16}$ Higher mortality among girls can be closely related to a general preference for sons in India, which is expressed in special treatment for boys in terms of parental investment in nutrition, vaccinations, access to health treatment and parental care in general. ${ }^{17}$ On the issue of education, the share of women teacher in India was below half. ${ }^{18}$ The decrease of women's labour force also occurred in India, ${ }^{19}$ includes a notable decline in labour force participation for women aged 25 to 54, where occupational segregation resulted in lack of job opportunities for women and that of job growth disproportionately benefited men. ${ }^{20}$

The aforementioned facts and statements seem so contradictive to positive views on women. Indeed, women in India have a special position. Mainly for Hindus, they are referred to as goddess Sarasvati, Laksmi, ${ }^{21}$ Kali, Durga. Ideally, this should lead Indians (devotees) to primarily respect women in an appropriate way.

The facts also undermine that many achievements of some Indian women are undeniably remarkable. This is to acknowledge Pioneer of women education in India Savitribai Phule, Prime Minister Indira (Priyadarshini) Gandhi, Nobel Laureates Mother Teresa (Saint Teresa of Calcutta), Vandana Shiva, Activist, Mathematician Mangala Narlikar, the Chairperson of Jindal Steel \& Power Limited Savitri Jindal, and Badminton player Pusarla Venkata Sindhu. Besides, many actresses of the Indian Movie Industry (the Bollywood) are also very famous over the world.

\subsection{Writing Purposes, Approaches, and Outline}

The present article highlights the issue of women in India. It has three purposes that are linked. First of all, it aims at describing the violence against women in India that degrades their dignity as a human being. It may be reasonably assumed that a

13 Gita Mittal, "Gender Equality : Contributions of Delhi High Court, in SMT," Nomita Aggarwal (Comp), All India Meeting of Chief Justices of High Courts on Women Empowerment Vis-A-Vis Legislation and Judicial Decisions, National Commission for Women, New Delhi, 11 December 2004 h.42, http://ncw. nic.in/pdfReports/All\%20India\%20Meeting\%20of\%20chief\%20Justice.pdf

14 United Nations, 2015. The World's Women 2015: Trends and Statistics. New York: United Nations, Department of Economic and Social Affairs, Statistics Division. Sales No. E.15.XVII.8.

15 Ibid., 5.

16 Ibid., 41

17 Ibid.

18 Ibid., 78.

19 Ibid., 89.

19 Ibid., 92.

20 In India traditionally women have been mentioned as the provider of food. Hindu scriptures have described goddess Laxmi as 'Annadatri' - which in Sanskrit means 'Food Giver".See "Women farmers of India: A Growing Force without a Growing Voice”,https://www.worldpulse.com/fr/node/12031. 
bunch of violence cases on women in India can't be a major player for development. This then leads to the second purpose of this article, to analyse both the conceptual and practical aspects of women, particularly with regards to their role in development. As the proper role in development can be achieved through a strong capacity, equality, and self-reliance, then it may be assumed that empowerment is a key element for development. This thus inspires and leads to the third goal of this article, to discuss the need for accelerating the empowerment of women in India. These three elements of aim will amount to the ultimate purpose of this writing: knitting the future story of the women in India.

This article is designed as a research in the field of Sociology and other related areas, among others, Law and Economics that focus on women, feminist, and gender issues. $^{22}$ It must be acknowledged that sociological researchs that have been carried out mostly suggested that the Indian women enjoy a low status in their households due to family decisions relating to finances, kinship relations and selection of life partner are made by the male members and women are rarely consulted. ${ }^{23}$

Apart from a sociological approach that mainly colours the analysis of this article, the legal approach will be also used besides some other approaches such as, culture and economic, in order to enrich the discourse. The legal approach is important to be utilized as, referring to Joginder S. Gandhi, law, legal norms, and legal impulses permeate India's entire social life and social system, including a variety of institutional settings such as the polity and administration. ${ }^{24}$

The structure of this writing is described as follows. The first part is Introduction that reveals the writing background and clarifies its purposes, approaches, and outline. It will then turn to discuss the main issues as described in Part 2: The Result and Analysis. This second part consists of three topics. The sub-topic of preventing violence against women in India will look on the general legal protection to the women in India and specific laws regulating the violence and crime against women in India and will also build argumentation that women status before the Indian law may lead to violence. The sub-topic of fostering women development in India will discuss the conceptual approaches that link women to the issues of development and the gender mainstreaming in India. The last subtopic, that is accelerating the empowerment of women in India, will analyze the current efforts by both government and nongovernment players/actors to empower the women capacity in India. This article

22 See for example Siuli Sarkar, Gender Disparity In India: Unheard Whimpers, (New Delhi: PHI Learning Private Limited, 2016), 10.

23 "Sociologyguide, Women's Position in India", http://www.sociologyguide.com/women-and-society/womens-position-in-india.php. Regarding sociological research on women in India, see also Manuela Ciotti, Dalit Women between Social and Analytical Alterity: Rethinking the 'quintessentially marginal' in Leela Fernandes (Ed), Routledge Handbook of Gender in South Asia, (London-New York: Routledge, 2014), 309.

24 Joginder S. Gandhi, "Research in Sociology of Law", in Yogesh Atal(Ed), Sociology and Social Anthropology in India, Dorling Kinderley, 2009, 560. 
will be finally ended with a concluding part that reflecting the current situation faced by women in India and proposing a work for their better future.

\section{Result and Discussion}

\subsection{Preventing Violence against Women in India}

This part describes legal issues of women in India, primarily based on the assumption that law, on one hand, can be a means to foster development, but on the other, can also be a barrier for women development in India. It will then discuss the legal protection to the women in India, violence against women in India, and vulnerable status of women before the Indian law that may lead to the violence.

\subsubsection{General Legal Protection to the Women in India}

Under international law, India is a State Party to the Convention on Elimination of all Forms of Discrimination against Women (CEDAW). It signed the Convention on 30 July 1980 and ratified on 9 July 1993 with certain reservations. ${ }^{25}$ India made two declarations to the CEDAW. First, with regard to Articles 5 (a) and 16 (1) CEDAW, it declares that it shall abide by and ensure these provisions in conformity with its policy of non-interference in the personal affairs of any Community without its initiative and consent. Second, with regard to Article 16 (2) CEDAW India declares that though in principle it fully supports the principle of compulsory registration of marriages, it is not practical in a vast country like India with its variety of customs, religions, and level of literacy." Besides declaration, India also submitted a reservation that emphasizes its position not to be bound by Article 29 (1) that regulates the means of dispute settlement regarding the interpretation and application of CEDAW.

India, with other global nations, is committed to Beijing Platform for Action and Convention on Rights of the Child to protect and empower its women and girls. ${ }^{26}$ This second most populous country in the world also endorses the Sustainable Development Goals (SDGs-2030), a widely accepted document that addresses some classical problems such as poverty, inequality, and violence against women. ${ }^{27}$

The National law of India covers some legal protections to the women. The Constitution of India recognizes the equality of status and of opportunity and assuring the dignity of the individual that applies to all Indian citizens, including women. Article 14 of the Indian Constitution guarantees equality before Law as well

25 http://nhrc.nic.in/documents/india_ratification_status.pdfDeclarations, Reservations and Objections to CEDAW, http://www.un.org/womenwatch/daw/cedaw/reservations-country.htm, http://ncw.nic. in/pdfReports/CEDAW\%20The\%20Reservations\%20And\%20Optional\%20Protocol.pdf.

26 See Maneka Sanjay Gandhi, "Restoring An Equal Opportunity In All Sphere of Life", http: / /www. womanachiever.in/restoring.php.

27 Ibid. 
as protection to all persons within Indian Territory. In addition, Article 15 of the Indian Constitution basically prohibits discrimination on the grounds of religion, race, caste, sex, and place of birth or any of them. ${ }^{28}$ Interestingly paragraph (3) of this article mentions that "Nothing in this article shall prevent the State from making any special provision for women and children". In Govt. of A.P. v. P.B. Vijayakumar, phrase "any special provision for women" in Article 15 (3) of the Indian Constitution means that the improvement of women's participation in all activities under the supervision and control of the State can be in the form of either affirmative action or reservation. ${ }^{29}$ Further, Article 23 of the Indian Constitution is designed to prohibit both forced labour and human trafficking. ${ }^{30}$ This provision is certainly a constitutional protection to the women in India, as there have been many cases of women trafficking. It can also be cited Article 46 of the Indian Constitution that determines the State to promote the educational and economic interests of the women and weaker sections of the people and also to protect them from social injustice and all forms of exploitation.

Indian national law also became a legal instrument for the establishment of the Indian National Commission for Women that was created through Act 1990. This Commission has the following mandates: review the constitutional and legal safeguards for women; recommend remedial legislative measures; facilitate redressal of grievances; and advise the Government on all policy matters affecting women. ${ }^{31}$

\subsubsection{Violence and Crime against Women in India}

In 2015, the Protection of Women from Domestic Violence Act was enacted. This Act inter alia covers the issues of definition of domestic violence, power and duties of protection officers, and procedure for obtaining orders of relief. ${ }^{32}$

As what has been explained in Part 1.1, a progressive law that is the Sexual Harassment of Women at Workplace Prevention, Prohibition, and Redressal Act 2013 was also created. It deals with complaints committee, a complaint mechanism, duties of employer, duties, and power of district officer. ${ }^{33}$ Two decades before this Act was issued, the Guidelines of the Supreme Court of India in August 1997 has prohibited sexual harassment of women at the workplace that is legally binding on all establishments and institutions. ${ }^{34}$ Today all major organizations have a cell called Internal

27 The Constitution of India, Arts 15 (1) and (2).

28 Govt. of A.P. v. P.B. Vijayakumar, (1995) 4 SCC 520, that: 8, http://www.pmindiaun.org/adminpart/uploadpdf/77442Annexure\%20II\%20of\%20the\%20UPR\%20National\%20Report.pdf.

29 The Constitution of India, Article 23 (1) and (2).

30 Official website, "National Commission for Women, India", http://ncw.nic.in/frmAboutUS.aspx See also National Commission for Women Act No. 20 of 1990, Chapter III, http://wcd.nic.in/sites/default/ files / ncwact.pdf.

31 "The Protection of Women from Domestic Violence Act of India", http://wcd.nic.in/sites/default/ files/wdvact.pdf.

32 "The Sexual Harassment of Women at Workplace Prevention, Prohibition, and Redressal Act 2013, Chapters I-VII," http://wcd.nic.in/sites/default/files/Sexual-Harassment-at-Workplace-Act.pdf.

33 Yugantar Education Society Civil Lines, 2004, A Research Study on the Nature, Incidence, Extent 
Complaints Committee (ICC) to address such complaints. Arundhati Bhattacharyya argues that law can be an effective instrument for bringing social change. ${ }^{35}$ The creation of specific laws for female employees also indicates how the law has been successfully used to achieve equilibrium by regulating socio-legal relationship. ${ }^{36}$

Research shows an interesting trend between the Law and the Crime against women. ${ }^{37}$ As analyzed, the laws seem to be designed to look at the crimes as almost a factor divorced from social customs and gender-based attitude. ${ }^{38}$ An obvious instance is that case of rape is definitely criminalized, but marital rape, unfortunately, is not penalized. ${ }^{39}$ Even a woman petitioned India's Supreme Court with a plea to declare marital rape a criminal offense, was dismissed. ${ }^{40}$

Crime against Women in India can be distinguished into two categories. The first category is Crime Heads under the Indian Penal Code (IPC), as follows: ${ }^{41}$

1. Rape (Sec. 376 IPC)

2. Attempt to Commit Rape (Sec 376/511 IPC).

3. Kidnapping and Abduction of Women (Section 363, 364, 364A, 365, 366 to 369 IPC)

4. Dowry Deaths (Section 304B IPC)

5. Assault on Woman with Intent to Outrage Her Modesty (Sec. 354 IPC)

6. Insult to the Modesty of Women (Sec. 509 IPC)

7. Cruelty by husband or his Relatives

8. Importation of Girl from Foreign Country (up to 21 years of age) (Sec. 366 B IPC)

9. Abetment of Suicide of Women (Sec. 306 IPC)

The second category is Crime Heads under the Special and Local Laws (SLL)

and Impact of Sexual Harassment of Women at Work Place in the State of Maharashtra Research Study, Report Submitted to Department of Women and Child Development, Ministry of Human Resource Development, Government of India. http://ncw.nic.in/pdfReports/A_Study_on_Impact_Of_SH_At_Work_Place_ In_Maharashtra.pdf See also Vishaka and others V. State of Rajasthan and others. (AIR 1997 SUPREME COURT 3011) J.S. Verma C.J.I., Mrs. Sujata V. Manohar and B.N. Kirpal. J.J. https://www.iiap.res.in// files/VisakaVsRajasthan_1997.pdf

34 Arundhati Bhattacharyya, Sexual Harassment in the Indian Bureaucracy: Violation of Human Rights (Cambridge Scholars Publishing, 2016), 43.

35 Ibid.

36 "Violence Against Women in India: The Crimes \& Their Causes", https://www.poverties.org/ blog/violence-against-women-in-india.

37 Ibid.

38 Ibid.

40 Dominique Mosbergen, "India's Marital Rape Crisis Reaches 'Tragic Proportions", http://www. huffingtonpost.com/entry/india-marital-rape_us_564d8c21e4b00b7997f9469e.

41 “Crime Against Women (Indian National Crime Records Bureau)", http://ncrb.nic.in/StatPublications / CII/CII2015/chapters/Chapter\%205-15.11.16.pdf. 
that are special Acts created for protection and safety of women, in which criminal cases recorded by police throughout the country. ${ }^{42}$ These include the Dowry Prohibition Act, 1961; The Indecent Representation of Women (Prohibition) Act, 1986; The Commission of Sati Prevention Act, 1987; The Protection of Women from Domestic Violence Act, 2005; and The Immoral Traffic (Prevention) Act, $1956 .{ }^{43}$

\subsubsection{Vulnerable Status of Women Before the Indian Law May Lead to Violence}

The general legal protection afforded to the women as discussed in art 2.1.1 seems a very basic protection. In facts, women groups have engaged in campaigns on several issues such as legal maintenance, guardianship, and custody of children, a uniform civil code, that demanded new legislations or changes in legislations to give justice to women and control violence, some activists actually wonder about the effectiveness of legislations. ${ }^{44}$

The case of divorce may be used as an example, as maintenance is granted under the different personal laws. ${ }^{45}$ It is clear that the disparity in the laws for the different communities adversely affects the women rights. ${ }^{46}$ An instance can be seen in Hindu community where wife is entitled to during a matrimonial proceeding has no ceiling and can be granted by judge's discretion meanwhile a Christian woman was not entitled to more than twenty percent of her husband's income. ${ }^{47}$ This ceiling has now been removed by the amendment Act of $2001 .{ }^{48}$

Under the Muslim law, there is no provision for maintenance after divorce. ${ }^{49}$ Particularly after the Shah Bano case and the passing of the 1986 Muslim Women's (Protection of Rights on Divorce) Act, Muslim women have no access to maintenance even under the Criminal Procedure Code. ${ }^{50}$ A certain extent by the Supreme Court interpretation of the Act can be seen in a case Danial Latifi vs. Union of India. ${ }^{51}$

Beyond the direct economic impact, assets in the hands of women have other welfare impacts. Land ownership can act as a protective factor for women against domestic violence. Research in the state of Kerala, a state where the literacy rate is

42 Ibid.

43 Ibid.

44 Ghanshyam Shah, "Social Movements In India A Review of Literature", 84, http://www.arvindguptatoys.com/arvindgupta/movement-shah.pdf..

45 Gaurav Sankalpand Shalini Agrawal, "Change in Behavior Pattern of Indian Married Women", International Journal of Sociology and Anthropology 5, No. 5 (2013), 148, http://www.academicjournals. org/journal/IJSA/article-full-text-pdf/EB84BFD5749

46 Ibid.

47 Ibid.

48 Ibid.

49 Ibid.

50 Ibid.

51 http://www.the laws.com/Encyclopedia/Browse/Case?CaseId=001002993100. 
100 percent $t^{52}$ and a minor matrilineal family system ${ }^{53}$ and also women are educated, show that 49 percent of women with no property reported physical violence and a mere of 7 percent with property reported physical violence. Thus the control lies in a wide range of factors. ${ }^{54}$ In common law countries, the judiciary has played an important role in developing the antidiscrimination law.

\subsection{Fostering Women Development in India}

\subsubsection{Conceptual Approaches: Linking the Women and the Issue of Development}

Fareda Banda discusses conceptual approaches that link the women and the issue of development as they evolved within the United Nations' framework. ${ }^{55}$ She acknowledges conceptual evolution from women in development (WID) to women and development (WAD) and finally, to gender and development (GAD). ${ }^{56}$

The Women in Development (WID) approach exposes how the conventional economic rationale for work involving women undermined their work and masked the magnitude of their economic role in society. ${ }^{57}$ In this approach, the recognition that women's experience of development and of societal change differed from that of men was institutionalized and it became legitimate for research to focus specifically on women's experiences and perceptions. ${ }^{58}$ Under some documents (e.g. DFID, then ODA) Women in Development specifies four main objectives, namely legal rights, access to planning public services, social status and access to education. ${ }^{59}$

Reports of the Secretary-General to the General Assembly of the United Nations show how the concept of WID is used and contemplated. On 22nd September 1995, a report entitled "Effective Mobilization and Integration of Women in Development: Gender Issues in Macroeconomic Policymaking and Development Planning" highlights that marginalization approach as a premise for the analysis of women in development

52 The Times of India, "Kerala becomes 1st State in Country to Achieve 100\% Primary Education", https: / timesofindia.indiatimes.com/india/Kerala-becomes-1st-state-in-country-to-achieve-100-primaryeducation/articleshow/50540263.cms.

53 Pralip Kumar Narzary and Shilpi Mishra Sharma, "Daughter Preference and Contraceptive-use in Matrilineal Tribal Societies in Meghalaya, India”, Journal of Health, Population and Nutrition, 31, No. 2 (2013): 1,https://www.ncbi.nlm.nih.gov/pmc/articles/PMC3702350/pdf/jhpn0031-0278.pdf.

54 UN Millennium Project 2005. "Taking Action: Achieving Gender Equality and Empowering Women", Task Force on Education and Gender Equality, p.9, http://www.undp.org/content/dam/aplaws/ publication/en/publications / poverty-reduction/poverty-website/taking-action-achieving-gender-equalityand-empowering-women/Taking\%20Action-\%20Achieving\%20Gender\%20Equality\%20and\%20Empowering\%20Women.pdf

55 Fareda Banda, "Women, Human Rights and Development",149, http://www.ohchr.org/Documents/Issues/Development/RTDBook/PartIIChapter11.pdf.

56 Ibid, 150.

57 Ibid.

58 Ibid.

59 Yumiko Yokozeki, "Gender in Education and Development", Journal of International Cooperation in Education 1, No.1 (1998): 56, http://home.hiroshima-u.ac.jp/cice/wp-content/uploads/publications/ Journal1-1/1-1-5.pdf. 
was considered irrelevant and unrealistic to be continuously relied on, as women have obtained a major place in the labour market and have also greater access to productive resources. ${ }^{60}$

WID has been criticized for some issues. This approach is considered not to handle the issue of the unequal gender relations and roles at the basis of women's exclusion and gender subordination rather than addressing the stereotyped expectations entertained by men. ${ }^{61}$ In addition, WID is also criticized for its views on the fact that women's status will improve by moving into productive employment, implying that the move to the "modern sector" need to be made from the "traditional" sector to achieve self-advancement.

The second approach, Women and Development (WAD) considers women economic activities, inside and outside their homes, as an essential surviving element of the family unit and also part of the development process. ${ }^{62}$ Further, it argues that the failure to integrate women as economic actors in their societies contributed to sustaining existing international structures of inequality. ${ }^{63}$ This approach has been widely used by nations over the world. In 1987, UN Secretary General reported that Economic Commission for Africa and the Economic and Social Commission for Western Asia have formulated specific activities relating to 'women and development' in a large and various program areas. ${ }^{64}$ Many women and development advocates have emphasized women NGO's as key actors in development. ${ }^{65}$ The WAD approach faced some critiques for overlooking the major influence of the ideology of patriarchy and thus being insufficiently gendered, for its failure to engage with issues of dependency (of third world States and women) on international capital and the resultant inequalities, and for the lack of class as a category of analysis. ${ }^{66}$

60 United Nations, 22 September 1995, "Report of the Secretary-General to the General Assembly of the United Nations (A/50/399), Effective Mobilization and Integration of Women in Development: Gender Issues in Macroeconomic Policy-making and Development Planning", par. 28, http://www.un.org/documents/ga/docs/50/plenary/a50-399.htm

61 Elvis Quincy, "Gender and Development Principles and Their Criticism”, 2, https: / /www.academia. edu/11708039/GENDER_AND_DEVELOPMENT_PRINCIPLES_AND_THEIR_CRITICISMS?auto=download

62 Banda, Op. Cit, 151.

63 Ibid

64 United Nations, 2 June 1987, "Report of the Secretary General of the United Nations, A/42/273, Strengthening the Work of the United Nations in Integrating Women Effectively in Economic Development Programmes and Activities," par.10,http://repository.un.org/bitstream/handle/11176/151515/ A_42_273\%3bE_1987_74-EN.pdf?sequence=1\&isAllowed=y.

65 Elvis Quincy, "Gender and Development Principles and Their Criticism", 2, https://www.academia.edu/1170 Shahrashoub Razavi Carol Miller, "From WID to GAD: Conceptual Shifts in the Women and Development Discourse", 41, http://www.unrisd.org/80256B3C005BCCF9/httpNetITFramePDF?Rea dForm\&parentunid=D9C3FCA78D3DB32E80256B67005B6AB5\&parentdoctype=paper\&netitpath=80256 B3C005BCCF9/ (httpAuxPages)/D9C3FCA78D3DB32E80256B67005B6AB5/\$file/opb1.pdf

66 Ibid. 
The first United Nations World Conference on Women was held in Mexico City in 1975 and one of the three objectives of this conference is the integration and full participation of 'women in development' while the conference urges Governments to formulate national strategies, targets and priorities through the establishment of the International Research and Training Institute for the Advancement of Women and the United Nations Development Fund for Women, which serve as an institutional framework for research, training and operational activities in the area of 'women and development'. ${ }^{67}$ In comparing the two approaches, WAD is generally thought to offer a more critical conceptualization of women's position than WID. ${ }^{68}$

The third approach, Gender and Development (GAD), is not specifically focused on the issue of women, but on the concern of the means in which a society assigns roles, responsibilities, and expectations, to both women and man. ${ }^{69}$ This approach is aimed at challenging structural discrimination. ${ }^{70}$ This latest approach does not means that GAD has never been criticized particularly as it emphasizes the social differences between men and women while neglecting the bonds between them and also the potential for change in roles and that GAD also does not uncover the types of trade-off that women are prepared to make for the sake of achieving their ideals of marriage or motherhood. ${ }^{71}$

\subsubsection{Gender Mainstreaming in India is A Need}

The topic of 'Women in India' is undoubtedly really broad. It cannot be covered even in a paper of hundred pages. Even a specific perspective like gender or feminism seems also very complicated. Maitrayee Chaudhuri emphasizes the importance of understanding the reasons for the difficulties involved, since the relationships between experience, the personal and the theoretical/political may well be more critical today than ever before in thinking about the future of women's studies and feminist politics in contemporary India. ${ }^{72}$

During the colonialism, gender has been a central 'issue' in India when an overwhelming preoccupation with the "woman's question" arose from the 19th-century social reform movement, crucially informed anti-colonial nationalism and remains a

\footnotetext{
67 http://www.5wwc.org/conference_background/1975_WCW.html.

68 Addison Hanne, Feminist Economics, WFS Publishing, 2015, 40.

69 Ibid, 41.

70 Banda, Loc. Cit.

71 Quincy, Op.Cit., 4.

72 Maitrayee Chaudhuri, "Learning through Teaching the 'Sociology of Gender", Indian Journal of Gender Studies 9, No. 2 (2002): 260, http://www.jnu.ac.in/faculty/maitrayee/Learning\%20through\%20
} Teaching.pdf. 
point of crisis in India's cultural, social, and political space. It entails that the basis of Indian women's movements recognition was formed by gender issue. ${ }^{73}$

Feminist movements in India can be seen in the agricultural sector like the Chipko Movement (1973) and the Cotton Movement (1986), ${ }^{74}$ where women agitated for their rights and duties. Chipko was popularized by the feminist movement, who pointed out that village women have to walk long distances to collect fuel and fodder and they become the first victims of forest destruction. ${ }^{75}$ Eco-feminists argued that women are therefore closer to nature and more ecologically conscious. ${ }^{76}$ These movements brought women to the fore as they were the ones who were directly affected due to the development and also government policies (although men were also part of the agitation).

Women in India and perhaps in other developing countries are generally homemakers, child bearers, and nurse the family who primarily take care of all the family members. Their contribution to the family is definitely huge and immeasurable. Unfortunately, their hard work for the family is often considered as a duty in nature and is often not regarded as a work in term of economics. In a comparative way, the same work done by women outside the household domain is paid and monetarily compensated by their employers. This leads to a social trend that women are more appreciated if they work outside the house and are neglected if they work in their own homes and family where the work is unrecognized, unpaid and a duty of the woman.

Like in many other countries as highlighted by the United Nations, India also faces the impacts of the recession, unemployment and slow economic growth, on women and men differ due to gender norms and stereotypes that continue to spread gender-based discrimination in many areas, including access to productive assets and justice. ${ }^{77}$ This hence leads to degradation in the status of the women; also her role and power were not given the right due and recognition.

In the patriarchal society of India, men have the ownership of the land. In Bihar, one of the most underdeveloped states of India with great natural resources, only

72 Samita Senn. April 2000, "Toward a Feminist Politics? The Indian Women's Movement in Historical Perspective, Policy Research Report on Gender and Development”, Working Paper Series No. 9, The World Bank Development Research Group/ Poverty Reduction and Economic Management Network, 1, http://unpan1.un.org/intradoc/groups/public/documents/apcity/unpan051009.pdf.

73 World Bank, "India Cotton and Textile Industries: Reforming to Compete," New Delhi: Allied Publishers, 2000, 28.

74 Malvika Poonia. Reinvestigating the Chipko Movement of 1973, International Journal of Environmental Sciences, 6. No.5, 2016. p.841.

75 Ibid.

76 See United Nations, 2012, "Women The Future Women Want: A Vision of Sustainable Development for All”, 5, http://www.uncclearn.org/sites/default/files/inventory/unwomen707.pdf. 
$1 \%$ of women are landowners. ${ }^{78}$ Single ownership in the woman's name or joint ownership in both names is still largely an untouched topic, a distant dream despite central and state government laws which allow equality of ownership. ${ }^{79}$

It can build an argument that gender mainstreaming in all sectors is a means to foster development in India. The concept of gender mainstreaming is defined by the United Nations Economic and Social Council (ECOSOC) as follows:

"Mainstreaming a gender perspective is the process of assessing the implications for women and men of any planned action, including legislation, policies or programmes, in all areas and at all levels. It is a strategy for making women's as well as men's concerns and experiences an integral dimension of the design, implementation, monitoring, and evaluation of policies and programmes in all political, economic and societal spheres so that women and men benefit equally and inequality is not perpetuated. The ultimate goal is to achieve gender equality". ${ }^{80}$

There have been some case studies that disseminate some practices of gender mainstreaming in India. In 2008, a United Nations Development Programme (UNDP) publication discover gender mainstreaming with specific and a number of themes that have been successfully practiced in many States in India. This includes Mobilizing Communities on Rights Awareness through the Saurashtra Kachchh group on Violence against Women in Gujarat, Rehabilitation of Victims of Human Trafficking by NGO Network in Meghalaya, and Empowering Women through Literacy in Uttarakhand. ${ }^{81}$ In 2011, Asian Development Bank also releases a report concerning gender mainstreaming in India that mentions three major projects: Urban Water Supply and Environmental Improvement in Madhya Pradesh Project (UDAY), Kolkata Environmental Improvement Project, and Tsunami Emergency Assistance (Sector) Project. ${ }^{82}$

Usha Bhasin, Officer on Special Duty, Doordarshan Prasar Bharati Broadcasting Corporation of India told to the world about India's experience with Mainstreaming Gender in Development and Business Models, particularly broadcasting. Interestingly, as informed, there has been a moderate and widely accepted program that embedded

77 "Women farmers of India: A Growing Force without a Growing Voice”, Loc. Cit.

78 Ibid.

79 United Nations, "Agreed conclusions 1997/2 on Mainstreaming A Gender Perspective Into All Policies and Programmes in the United Nations System", Official Records of the General Assembly, Fiftysecond Session, Supplement No. 3 (A/52/3/Rev.1), chap. IV, para. 4, http://www.un.org/womenwatch/ osagi/pdf/ECOSOCAC1997.2.PDF.

80 United Nations Development Programme, 2008, "Good Practices in Gender Mainstreaming Case Studies From India”, http://www.undp.org/content/dam/india/docs/good_practices_in_gender_mainstreaming.pdf.

81 Asian Development Bank, 2011, “Gender Mainstreaming, Case Studies: India," https://www. adb.org/sites/default/files/publication/29934/gender-mainstreaming-case-studies-india.pdf. 
gender issues in any theme without explicitly branded it as a 'women' program or 'about women'. ${ }^{83}$

Maitrayee Chaudhuri, a Social Science scholar at Jawaharlal Nehru University, New Delhi, revealed that there appears to have been an unspoken consensus that women's studies is a mainstream field and can, therefore, be made mandatory. She also thought that gender studies have been sufficiently mainstreamed to be incorporated into a topic of sociology seminars, a book chapter, or a topic on the reading list of a mainstream course. ${ }^{84}$

\subsection{Accelerating Empowerment of Women in India}

A recent study carried out by Endalcachew Bayeh regarding empowering women with regards to the issue of sustainable development in Ethiopia stated that sustainable development is impossible without women's empowerment and gender equality. ${ }^{85}$ The study recommends the government to take the following measures, inter alia, empowering women and making full use of their labour force for economic growth; educating and maintaining the health of women to enhance productivity and social development; providing women with fair representation across different decision-making levels of the government structure to better protect women's interests and to achieve quality governance; and protecting women rights to ensure their active participation in a wide-range arena of the country. ${ }^{86}$

The concern of Government of India for implementing various schemes for rural women's welfare should be appreciated. There are at least 16 women empowerment schemes provided by the Ministry of Women and Child Development of the Government of India. ${ }^{87}$ One of them is UJJAWALA, a Comprehensive Scheme for Prevention of Trafficking and Rescue, Rehabilitation and Re-Integration of Victims of Trafficking for Commercial Sexual Exploitation that has been effective since 1 April 2016. The targeted group of this scheme is women and children who are vulnerable or victims of trafficking for commercial sexual exploitation. ${ }^{88}$ Another scheme is Swadhar Greh that was introduced in 2015 that caters to primary needs of women in difficult

82 Usha Bhasin, "India's experience with Mainstreaming Gender in Development and Business Models", http:/ / www.unesco.org/fileadmin/MULTIMEDIA/HQ/CI/CI/pdf/Events/gfmg_usha_bhasin.pdf.

83 Chaudhuri, Op.Cit., 247-248.

84 Endalcachew Bayeh, "The Role of Empowering Women and Achieving Gender Equality to the Sustainable Development of Ethiopia," Pacific Science Review B: Humanities and Social Sciences 2 (2016), 38, http:/ / ac.els-cdn.com/S2405883116300508/1-s2.0-S2405883116300508-main.pdf?_tid=f5384b4c5b19-11e7-909f-00000aab0f26\&acdnat=1498555450_164b427a4b1643040834e9b8f2514f0a

85 Ibid., 42.

86 Ministry of Women and Child Development of the Government of India, "Women Empowerment Schemes",http://wcd.nic.in/schemes-listing/2405.

87 Ministry of Women and Child Development of the Government of India, "Comprehensive Scheme for Prevention of Trafficking and Rescue, Rehabilitation and Re-Integration of Victims of Trafficking for Commercial Sexual Exploitation", 3, http://wcd.nic.in/sites/default/files/Ujjawala\%20New\%20Scheme.pdf. 
circumstances that is aimed, among others, to cater to the primary need of shelter, food, clothing, medical treatment and care of the women in distress and who is without any social and economic support. ${ }^{89}$ It provides legal services, vocational training, medical facilities, and counselling for beneficiaries above 18 years of age who are deserted and are without any social and economic support, survivors of natural disasters, prisoners released from jail, victims of domestic violence, trafficked women/girls rescued, and women affected by HIV/AIDS. ${ }^{90}$

The Draft National Policy for Women 2016, 'Articulating a Vision for Empowerment of Women, May 2016 'seems very promising for women development in India. ${ }^{91}$ It envisions a society in which, women attain their full potential and are able to participate as equal partners in all spheres of life and influence the process of social change. ${ }^{92}$ This draft of policy covers six priority areas: health including food security and nutrition; education; economy; governance and decision making; violence against women; enabling environment; and environment and climate change. ${ }^{93}$ Interestingly, one of its objectives is mainstreaming gender in all-round development processes/programs / projects / actions. ${ }^{94}$

Interestingly, a number of banks provide microfinance to women groups that foster the development of women in India. The first example is the Mann Deshi Mahila Sahakari Bank that was established in 1997 for and by rural women with a mission of rural economic empowerment, by providing capital and other financial services to impoverished women. ${ }^{95}$ Currently, it has seven branches and has served over 200,000 women in Maharashtra and become the second largest microfinance bank in India, with a 98\% repayment rate. ${ }^{96}$ The second instance is the Swashrayi Mahila Sewa Sahakari Bank that is owned by the self-employed women as shareholders where the policies are formulated by their own elected Board of women workers. ${ }^{97}$ SEWA is an abbreviation of Self Employed Women's Association that is a trade union registered in 1972, an organization of poor and self-employed women workers who earn a living through their own labour or small businesses. ${ }^{98}$

88 Guidelines, "Swadhar Greh: Scheme that Caters to Primary Needs of Women in Difficult Circumstances (2015)”, 1, http://wcd.nic.in/sites/default/files/Guidelines7815_2.pdf.

89 Ibid., 2 \& 7.

90 Ministry of Women and Child Development of the Government of India, May 2016, "Draft National Policy for Women 2016, Articulating a Vision for Empowerment of Women,” http://wcd.nic.in/sites / default/files/draft\%20national\%20policy\%20for\%20women\%202016_0.pdf

91 Ibid., Part 2.

92 Ibid., Part 5.

93 Ibid., Part 4.

94 http://www.manndeshibank.com/Bank_About\%20Us.html.

95 Ibid.

96 http://www.sewa.org/Services_Bank.asp.

97 http://www.sewa.org/About_Us.asp. 
The Non-Governmental Organizations (NGOs) also play a role in working for women empowerment. India Women Welfare Foundation (IWWF) can be a perfect example. It commits to empower women through education, vocation, motivation, and inspiration, which leads towards their growth and sustainable development, shall be adhered to. ${ }^{99}$

\section{Conclusion}

Some cases of violence against women as discussed in Part 2.1. should be contemplated. Both socio-cultural and legal approaches should work hand in hand. On one hand, socio-cultural obstacles related to patriarchy and stereotypes that demean women should be dealt with a gender approach. On the other hand, legislations should be enacted and modified to provide more protection in favour of women while law enforcement should also be taken seriously.

Part 2.2. that analyses conceptual approaches and facts regarding women and development in India is an indication of the dynamic development of Indian women. They have a good history of successful movements that brought them to the arena where they could directly affect the development and also government policies. The efforts of mainstreaming gender are also positive signs of shifting them to a higher level of development.

The analyses in Part 2.3 stimulates that the acceleration of women empowerment in India is, inevitably, a necessity. The initiatives by the Government of India, particularly programs carried out by Ministry of Women and Child Development, so far, have indicated the concern of government to empower its women. It must be taken into note that some non-governmental actors have also played a crucial role in this concern. This dual approach, both government and non-government, should be further maximized in order to accelerate women empowerment in India.

The concern of the Government of India to the Sustainable Development Goals (SDGs), as has been previously explained in Part 2.1.1, seems so promising. On the goal 'achieve gender equality and empower all women and girls', it is targeted inter alia ensures women's full and effective participation and equal opportunities for leadership at all levels of decision-making in political, economic and public life; Undertake reforms to give women equal rights to economic resources, as well as access to ownership and control over land and other forms of property, financial services, inheritance and natural resources, in accordance with national laws; and to adopt and strengthen sound policies and enforceable legislation for the promotion of gender equality and the empowerment of all women and girls at all levels. ${ }^{100}$

98 "Women Welfare", http://www.womenwelfare.org/support_women.html.

99 "Sustainable Development Goals (SDGs), Targets, CSS, Interventions, Nodal and other Ministries (As on 08.06.2016)", Parts 5.5, 5.a and 5.b, http://niti.gov.in/writereaddata/files/SDGsV20-Mapping080616-DG_0.pdf 
It is a dream for both rural and urban women in India to be very much aware of their rights, privileges and enjoy the freedom and the rights bestowed upon them: a dream where they have good access and opportunities to obtain higher education and excel in sports, arts, music, and business. And a dream where they could proportionally compete with men, do as well or even better than men in many areas. These may not be just dreams but our upcoming future.

No matter how the women in society are treated, ignored or suppressed, it must be recognized that their role is very vital in the process of development of the family, society/community, and even the nation. Now is the time for women in India to take part in the efforts to knit their future story by leaving the unpleasant experiences of the past, carefully observing and learning the present situ ation and jointly working for the future higher levels of development. 


\section{BIBLIOGRAPHY}

\section{Book}

Atal, Yogesh, ed. Sociology and Social Anthropology in India. New Delhi: Dorling Kinderley-Pearson Education, 2009.

Bhattacharyya, Arundhati. Sexual Harassment in the Indian Bureaucracy: Violation of Human Rights. Cambridge Scholars Publishing. 2016

Fernandes, Leela, ed. Routledge handbook of gender in South Asia. London-New York-Routledge, 2014

Hanne, Addison. Feminist Economics. WFS Publishing. 2015

Sarkar, Siuli. Gender Disparity In India: Unheard Whimpers. New Delhi: PHI Learning Pvt. Ltd., 2016.

\section{Journal}

Bayeh, Endalcachew. "The role of empowering women and achieving gender equality to the sustainable development of Ethiopia." Pacific Science Review B: Humanities and Social Sciences 2, no. 1 (2016): 37-42. https://doi.org/10.1016/j.psrb.2016.09.013

Chaudhuri, Maitrayee. "Learning through teaching the'sociology of gender'." Bulletin (Centre for Women's Development Studies) 9, no. 2 (2002): 245-261. https://doi. org/10.1177/097152150200900208

Mangoli, R. N., and Ganapati N. Tarase. "Crime against women in India: A statistical review." International Journal of Criminology and Sociological Theory 2, no. 2 (2009). https:/ /ijcst.journals.yorku.ca/index.php/ijcst/article/view/23401

Narzary, Pralip Kumar, and Shilpi Mishra Sharma. "Daughter preference and contraceptive-use in matrilineal tribal societies in Meghalaya, India." Journal of health, population, and nutrition 31, no. 2 (2013): 278. https://www.ncbi.nlm. nih.gov/pmc/articles/PMC3702350/

Poonia, Malvika. "Reinvestigating the Chipko movement of 1973." International Journal of Environmental Sciences 6, no. 5 (2016): 837-845. https://doi.org/10.6088/ ijes. 6078

Sankalp, Gaurav, and Shalini Agrawal. "Change in behavior pattern of Indian married women." International Journal of Sociology and Anthropology 5, no. 5 (2013): 147152. https://doi.org/10.5897/IJSA12.012 
Yokozeki, Yumiko. "Gender in Education and Development". Journal of International Cooperation in Education 1, No.1 (1998): 45-63. http:/ / home.hiroshima-u. ac.jp/cice/wp-content/uploads / publications/Journal1-1/1-1-5.pdf

\section{Legal Document}

The Constitution of India

National Commission for Women Act No. 20 of 1990

Protection of Women from Domestic Violence Act of India, 2005

Sexual Harassment of Women at Workplace Prevention, Prohibition, and Redressal Act 2013

Convention on Elimination of all Forms of Discrimination against Women

United Nations. "Agreed conclusions 1997/2 on Mainstreaming A Gender Perspective into All Policies and Programmes in the United Nations System". Official Records of the General Assembly, Fifty-second Session. Supplement No. 3 (A/52/3/ Rev.1). http://www.un.org/womenwatch/osagi/pdf/ECOSOCAC1997.2.PDF

United Nations. 2015. The World's Women 2015: Trends and Statistics. New York: United Nations, Department of Economic and Social Affairs, Statistics Division. Sales No. E.15.XVII.8

United Nations Millennium Project 2005. “Taking Action: Achieving Gender Equality and Empowering Women." Task Force on Education and Gender Equality. http:/ / www.undp.org/content/dam/aplaws / publication/en/publications / poverty-reduction/ poverty-website/taking-action-achieving-gender-equalityand-empowering-women/Taking\%20Action-\%20Achieving\%20Gender\%20 Equality\%20and\%20Empowering\%20Women.pdf

United Nations. 2 June 1987. "Report of the Secretary General of the United Nations, A/42/273, strengthening the Work of the United Nations in Integrating Women Effectively in Economic Development Programmes and Activities." http://repository.un.org/bitstream/handle/11176/151515/A_42_273\%3bE_1987_74EN.pdf?sequence $=1 \&$ isAllowed $=\mathrm{y}$

United Nations. 22 September 1995. "Report of the Secretary General to the General Assembly of the United Nations (A/50/399), Effective Mobilization and Integration of Women in Development: Gender Issues in Macroeconomic Policy-making and Development Planning". http://www.un.org/documents/ga/docs/50/plenary/ a50-399.htm 
United Nations. 2012. "Women The Future Women Want: A Vision of Sustainable Development for All". http://www.uncclearn.org/sites/default/files/inventory/ unwomen707.pdf

\section{Other Document}

Asian Development Bank. 2011. "Gender Mainstreaming, Case Studies: India". https: / / www.adb.org/sites / default/files / publication/29934 / gender-mainstreaming-case-studies-india.pdf

Mittal, Gita. "Gender Equality: Contributions of Delhi High Court, in SMT". Nomita Aggarwal (Comp), All India Meeting of Chief Justices of High Courts on Women Empowerment Vis-A-Vis Legislation and Judicial Decisions, National Commission for Women, New Delhi, 11 December 2004.http://ncw.nic.in/pdfReports/ All\%20India\%20Meeting\%20of\%20chief\%20Justice.pdf

"Crime Against Women (Indian National Crime Records Bureau)". http://ncrb.nic. in/StatPublications/CII/CII2015/chapters/Chapter\%205-15.11.16.pdf

Guidelines. "Swadhar Greh: Scheme that Caters to Primary Needs of Women in Difficult Circumstances (2015)". http://wcd.nic.in/sites/default/files/ Guidelines7815_2.pdf

http://ncw.nic.in/pdfReports /A_Study_on_Impact_Of_SH_At_Work_Place_In_Maharashtra.pdf

Ministry of Women and Child Development of the Government of India. "Comprehensive Scheme for Prevention of Trafficking and Rescue, Rehabilitation and Re-Integration of Victims of Trafficking for Commercial Sexual Exploitation". http:/ / wcd.nic.in/sites/default/files/Ujjawala\%20New\%20Scheme.pdf

Ministry of Women and Child Development of the Government of India. "Women Empowerment Schemes”. http://wcd.nic.in/schemes-listing/2405

Ministry of Women and Child Development of the Government of India. May 2016. "Draft National Policy for Women 2016, Articulating a Vision for Empowerment of Women". http://wcd.nic.in/sites/default/files/draft\%20national\%20policy\%20for\%20women\%202016_0.pdf

Samita. April 2000. "Toward a Feminist Politics? The Indian Women's Movement in Historical Perspective, Policy Research Report on Gender and Development". Working Paper Series No. 9, The World Bank Development Research Group/ Poverty Reduction and Economic Management Network. http://unpan1. un.org/intradoc/groups/public/documents/apcity/unpan051009.pdf 
Quincy, Elvis. "Gender and Development Principles and Their Criticism”. https:// www.academia.edu/11708039/GENDER_AND_DEVELOPMENT_PRINCIPLES_ AND_THEIR_CRITICISMS?auto=download

"Sustainable Development Goals (SDGs), Targets, CSS, Interventions, Nodal and other Ministries (As on 08.06.2016)". http://niti.gov.in/writereaddata/files/ SDGsV20-Mapping080616-DG_0.pdf

United Nations Development Programme. 2008. "Good Practices in Gender Mainstreaming Case Studies from India". http://www.undp.org/content/dam/india/ docs/good_practices_in_gender_mainstreaming.pdf

World Bank. "India Cotton and Textile Industries: Reforming to Compete". New Delhi: Allied Publishers. 2000

Yugantar Education Society, Civil Lines. 2004. "A Research Study on the Nature, Incidence, Extent and Impact of Sexual Harassment of Women at Work Place in the State of Maharashtra Research Study". Report Submitted to Department of Women and Child Development, Ministry of Human Resource Development, Government of India

\section{Case Law}

Danial Latifi Vs. Union of India (Supreme Court). 2001

Govt. of A.P. v. P.B. Vijayakumar, (1995) 4 SCC 520

Vishaka and others Vs. State of Rajasthan and others (AIR 1997 SUPREME COURT $3011)$ J.S. Verma C.J.I., Mrs. Sujata V. Manohar and B.N. Kirpal. J.J

\section{Website Content/Internet}

"10 of the Most Dangerous Countries to be A Woman". https://www.theneweconomy. com/insight/10-of-the-most-dangerous-countries-to-be-a-woman

"Acid Attack: Indian Court Sentences to Death for Murder after Marriage Proposal Rejected". 9 September 2016, http://www.abc.net.au/news/2016-09-09/ acid-attack-indian-court-sentences-man-to-death-for-murder /7828180

Banda, Fareda. "Women, Human Rights and Development". http: / /www.ohchr.org/ Documents/Issues/Development/RTDBook/PartIIChapter11.pdf

Bhasin, Usha. "India's experience with Mainstreaming Gender in Development and Business Models". http://www.unesco.org/fileadmin/MULTIMEDIA/HQ/ $\mathrm{CI} / \mathrm{CI} /$ pdf/Events/gfmg_usha_bhasin.pdf 
"Best and Worst Things that Happened to Women in 2014," https://www.jaagore. $\mathrm{com} /$ power-of-49/best-and-worst-things-that-happened-to-women-in2014

Gandhi, Maneka Sanjay. "Restoring An EqualOpportunity In All Sphere of Life". http://www.womanachiever.in/restoring.php

http://ncw.nic.in/pdfReports/CEDAW\%20The\%20Reservations\%20And\%200ptional\%20Protocol.pdf

http://nhrc.nic.in/documents/india_ratification_status.pdfDeclarations

http://www.5wwc.org/conference_background/1975_WCW.html

http://www.manndeshibank.com/Bank_About\%20Us.html

http://www.sewa.org/About_Us.asp

http://www.sewa.org/Services_Bank.asp

http:/ / www.the-laws.com/Encyclopedia/Browse/Case?CaseId=001002993100

http://www.un.org/womenwatch/daw/cedaw/reservations-country.htm

Human Rights Watch. "Treated Worse than Animals: Abuses against Women and Girls with Psychosocial or Intellectual Disabilities in India". https://www. hrw.org/report/2014/12/03/treated-worse-animals/abuses-against-women-and-girls-psychosocial-or-intellectual

Kolaskar, Ashok S. and Dash, Motilal (eds.). "Review on Women and Society: The Road to Change". http://www.socresonline.org.uk/18/3/reviews/3.html

Miller, Shahrashoub Razavi Carol. "From WID to GAD: Conceptual Shifts in the Women and Development Discourse”. http:/ / www.unrisd.org/80256B3C005BCCF9/ httpNetITFramePDF?ReadForm\&parentunid=D9C3FCA78D3DB32E80256B 67005B6AB5\&parentdoctype=paper\&netitpath $=80256 \mathrm{~B} 3 \mathrm{C005BCCF9} / \mathrm{htt}-$ pAuxPages)/D9C3FCA78D3DB32E80256B67005B6AB5/\$file/opb1.pdf

Mosbergen, Dominique. "India's Marital Rape Crisis Reaches Tragic Proportions". http:/ / www.huffingtonpost.com/entry/india-marital-rape us_564d8c21e4b00b7997f9469e

"Michelle Obama to Honour Acid Attack Victim Laxmi". http:/ /www.thehindu.com/ news/international/world/michelle-obama-to-honour-acid-attack-victimlaxmi/article5750391.ece

Official Website. "National Commission for Women, India". http://ncw.nic.in/frmAboutUS.aspx 
"Sociology Guide, Women's Position in India". http://www.sociologyguide.com/ women-and-society/womens-position-in-india.php

Swami Agnivesh, Rama Mani and Angelika Köster-Lossack. "Missing: 50 Million Indian Girls". http://www.nytimes.com/2005/11/25/opinion/missing-50million-indian-girls.html

Shah, Ghanshyam. "Social Movements in India: A Review of Literature". http:// www.arvindguptatoys.com/arvindgupta/movement-shah.pdf

"The Protection of Women from Domestic Violence Act of India". http://wcd.nic.in/ sites/default/files /wdvact.pdf

"The Sexual Harassment of Women at Workplace Prevention, Prohibition, and Redressal Act 2013, Chapters I-VII.” http://wcd.nic.in/sites/default/files/ Sexual-Harassment-at-Workplace-Act.pdf

The Times of India. "Kerala becomes 1st State in Country to Achieve 100\% Primary Education". https://timesofindia.indiatimes.com/india/Kerala-becomes-1st-state-in-country-to-achieve-100-primary-education / articleshow/50540263.cms

"Violence Against Women in India: The Crimes \& Their Causes". https://www.poverties.org/blog/violence-against-women-in-india

“Why India Bad for Women?". https://www.theguardian.com/world/2012/jul/23/ why-india-bad-for-women

"Women farmers of India: A Growing Force without a Growing Voice". https://www. worldpulse.com/fr/node/12031

"Women Welfare". http://www.womenwelfare.org/support_women.html 